\title{
PÉCHY BENJAMIN SZÍNES KRÉTÁI
}

\section{Kovács ZsuZsAnNA}

\author{
a Béri Balogh Ádám Gimnázium és Kollégium pedagógusa \\ kzsazsa@freemail.hu
}

A színes krétákról mindig Péchy Benjamin jut eszembe. Különösen a sárgát és a pirosat szeretem. Talán azért, mert e két szín mutat legjobban a táblán, de lehet, hogy azért, mert ö is ezeket használta leggyakrabban.

Gimnáziumi pályafutásom kezdete (1965, Gyönk, Tolnai Lajos Gimnázium) nem volt zökkenőmentes. Az általános iskolai bizonyítványomban a „Számtan és mértan" tantárgynál négyes virított; az év eleji felmérőt közepesre írtam meg, így korrepetálásra kellett járnom; alig telt el két hét középiskolás életemből, amikor kórházba kerültem, s két hétig az ágyat nyomtam. Mi lesz ebből? Természetesen, aztán minden elrendeződött. Mulasztásomat bepótoltam, s menet közben rájöttem, nem is olyan nehéz a matematika. Igaz, ehhez a felismeréshez Péchy tanár úr személye is kellett.

A kék szemü, fekete hajú fiatal tanár önmagában is kivívhatta volna rajongásunkat, de ehhez még hozzájárult kifogástalan megjelenése, mindig- hófehér köpenye, no meg persze - ami a legfontosabb - kristálytiszta magyarázata.

Amikor végre elkezdtük a gimnáziumi anyagot, nem volt többé problémám a matematikával. Az első ötös dolgozatom után még kételkedett egy kicsit (pedig első padban ültem, így puskázásról szó sem lehetett), de amikor a második is jelesre sikerült, meghívott a matematika szakkörbe. Ez történt Sanyival is, pedig ö - ami a tantárgyat illeti - még „mélyebbröl” indult. A mai diákok azt mondanák: szappanoperába illö karriertörténet. Én azonban másképp éltem meg. Péchy Benjamin a gátlásos gyerekben meglátott valamit. Szorgalmat? Kitartást? Inkább a fejlődőképességet. Azzal, hogy bekerültem a matematika „elitjébe”, bizalmat szavazott nekem, és egyben felelősséget rakott a vállamra: meg kell felelnem a Tanár Úr elvárásainak. Ugyanakkor úgy éreztem magam, mint aki nagy kitüntetésben részesült. Ha egy tanár ilyen lépésre szánja el magát, akkor lehet, hogy mégis van bennem 
valami... Akkor még nem tudtam, milyen szakot fogok választani a továbbtanulásnál, csak egyben voltam biztos: tanítani szeretnék. A nagy kedvenc az irodalom volt, a matematikát csak kóstolgattam.

Aztán jött egy döntő pillanat. Óra előtt rendetlenkedtünk, én a táblánál szórakoztattam az osztályt. A Tanár Úr olyan észrevétlenül jött be, hogy nem volt időm a helyemre iszkolni. Nem kiabált velünk, ez szintén jellemző volt rá: nem emlékszem arra, hogy valaha is felemelte volna a hangját. Azt mondta, megbocsát nekünk, ha valaki a házi feladatot a táblánál megoldja. Igyekeztem nem én lenni az a valaki, de nem volt menekvés. Ráadásul az osztálytársak is rám mutogattak, ha már úgyis ott vagyok a táblánál... Életemben elöször akkor volt a kezemben demonstrációs körző, s felajánlotta, használhatom a színes krétáit. Nem volt könnyü a házi feladat, de a szerkesztésem pontos és a színek miatt áttekinthető lett. „Ennél jobban nekem sem sikerült volna" - mondta. Madarat lehetett volna fogatni velem. Dicsérete elég volt ahhoz, hogy feltegyem a kérdést: jó lennék én matektanárnak?

Még egy évig tanított bennünket, ekkor az osztályfönökünk is volt. Mint a legtöbb kamasz, én is próbálkoztam versírással. Zsengéimet neki mutattam meg elöször. „Miért nekem?” - kérdezte az egyik osztálytalálkozón. Mert tudtam, hogy nem fog kinevetni, ugyanakkor megmondja azt is, ha rosszak az írásaim (ezt meg is tette), de ezt olyan pedagógiai érzékkel, hogy ne bántson meg. Mindezt tizenhat évesen még nem tudtam így megfogalmazni, csak éreztem, hozzá kell fordulnom.

Az egyik osztályfőnöki órán a pályaválasztásról beszélgettünk. Mindenki felvázolta az elképzelését. Noémi valami olyasmit mondott, ő nem elég okos ahhoz, hogy egyetemre menjen, de a gyerekeket nagyon szereti, így a tanítóképzőt célozza meg. A Tanár Úr ezt másképp látta. Szerinte az óvónőknek és a tanítóknak kell a legfelkészültebbeknek lenniük, hiszen a kisgyerek velük találkozik elöször a nevelési folyamatban. Ha az alapozás nem jó, később nehéz korrigálni. Persze ebből nem következett, hogy közülünk mindenki tanítónak ment volna, de elgondolkodtunk a mondottakon, s valószínü, Noémi önbizalmának is jót tett, amit hallott.

Aztán szétváltak útjaink. Költő nem lett belőlem, de matematikatanár igen. A rendezett táblakép és a színes kréták, no meg a körző és a vonalzó immár 34 éve hü társaim.

Aki a hatvanas években volt diák, tudhatja, hogy tanáraink élete nem volt nyitott könyv számunkra. Az, hogy ki is Péchy Benjamin, csak később, az ötévenként megrendezett osztálytalálkozókon rajzolódott ki előttem.

Azt, hogy Szekszárdra ment tőlünk, tudtuk. Arra, hogy felhagyott a matematika tanításával, csak később derült fény. Feltettem neki a kérdést: miért? Azt mondta, nagyon szerette a tanítványait, szakmai sikerekben is volt része, de úgy érezte, nem tud eléggé fejlődni, nem itt tud kiteljesedni.

Életútjának fontos állomása volt a pályaválasztási tanácsadó intézet, de azt hiszem, azok számára, akik már korábban is ismerték, nem meglepő, hogy elvégezte a pedagógia szakot. „Édesapám tanító volt” - mondta egyszer, mintha a világ leg- 
természetesebb dolga lenne: azért lett ő is tanár. Bizonyos esetekben a minta valóban „öröklődik”. Náluk a tanári, tanítói pálya családi tradíció volt, amit a következő generáció, a leánya is követett. A mostani tizenévesek nem így látják. Több pedagógusgyereket is tanítok, de senki nem akar a szülök nyomdokába lépni. Valami nagyon megváltozott. De ezt már nem tudom a Tanár Úrral megbeszélni...

1981-től a szekszárdi pedagógiai föiskolán dolgozott. Az, hogy nemcsak a hallgatókat tanította, hanem mintegy ötven szakmai publikációja jelent meg, neki természetes volt, hozzá tartozott a munkájához; azt, hogy ő „doktor”, akkor tudtam meg, amikor egy tanítványomat felvételizni kísértem a főiskolára; azt, hogy számos kitüntetést kapott, nem tőle tudom.

Ötévenként találkoztunk, és mindig ott tudtuk folytatni, ahol elözőleg abbahagytuk. Ritkán beszélt magáról, mindig bennünket faggatott: hogyan élünk, mivel foglalkozunk, mit olvasunk? És persze nosztalgiáztunk. Szerette Gyönköt, és szeretett bennünket. Soha nem akart senkit az akarata ellenére megváltoztatni.

2004 októberében találkoztunk utoljára. Szóba került a betegsége. „De már jól vagyok" - mondta, és én elhittem. Nem gondoltam akkor, hogy meg kellene hajtogatnom azt az ezer darut (japán szokás) a gyógyulásáért.

Emlékszem, az egyik egyetemi évfolyamtársam - nem sokkal a diplomaosztó elött - így fogalmazott: én nem matematika-fizika szakos tanár akarok lenni, hanem pedagógus. Nagyon szép gondolat. Péchy Benjamin már akkor pedagógus volt, amikor bennünket tanított. Nem véletlen hát, hogy e tudománynak szentelte életét. 